\title{
冷却熱応力による脆性き裂の進展形態に関する研究*
}

\author{
坂上賢一*1, 山田隆 亮*2, 隆雅 久*1
}

\section{A Study on Propagation Patterns of Thermally Induced Cracks in a Brittle Solid}

\author{
Kenichi SAKAUE*3, Ryusuke YAMADA and Masahisa TAKASHI \\ *3 Department Mechanical Engineering, Aoyama Gakuin University, \\ 5-10-1 Fuchinobe, Sagamihara-shi, Kanagawa, 229-8558 Japan
}

\begin{abstract}
When hot glass plates are quenched with cold water, several crack propagation patterns such as straight, oscillating or branching cracks, appear. In the present study, the authors examined the effect of temperature gradient on the crack propagation patterns in quenching glass plates experimentally. The temperature gradient in the glass plate is controlled by the temperature difference between the hot glass plate and the cold bath, and by descending speed into the cold bath. The experimental results show that the crack propagation pattern changes from a straight crack to an oscillating crack, then to a branching crack with increasing temperature difference and with decreasing descending speed. Also crack propagation pattern depends on plate width. Furthermore, the results shows that the crack propagation direction is strongly affected by specimen boundary.
\end{abstract}

Key Words : Fracture Mechanics, Brittle Fracture, Thermal Stress, Crack Propagation, Elasticity, Nonlinear Problem

\section{1. 序 論}

物体の温度が変化するとき, 物体内部の温度勾配に 基づく変形拘束によって熱応力が発生する.こうした 熱応力がき裂進展駆動力となり準静的な脆性破壊が生 じることは古くから知られている(1). 近年では, 熱応 力による破壊を利用した脆性材料の切断加工 ${ }^{(2)}{ }^{(3)}$ に おいて, 熱応力による破壊の予測と制御が重要となっ ている. その一方で, 熱応力によって発生するき裂は, 蛇行, 分岐といった複雑な進展形態を示すことがあり, このような場合においても, 破壊経路を予測すること が必要である.

熱応力によって発生するき裂の種々の破壊形態への 遷移条件に関しては，これまで主に物理的な立場から 調べられてきた。特に, き裂進展形態が直進から蛇行へ と遷移するときの条件は, ガラス中を伝播する脆性き 裂の実験的研究によって詳細に調べられている ${ }^{(4)}$ ( (6) . また, 伝播形態が直進から蛇行へと遷移するときの条 件を理論的に説明する試みもなされている(7) (13). し かし, 蛇行を絽り返しながら進展している際の, き裂

$*$ 原稿受付 2006 年 2 月 20 日.

*1 正員, 青山学院大学理工学部(昰229-8558 相模原市淵野辺 5-10-1).

*2 青山学院大学理工学部.

E-mail : sakaue@ me.aoyama.ac.jp
先端応力場に関しては十分に理解されていない。

脆性材料中のき裂は, き裂先端近傍の最大主応力に 対して垂直な方向, あるいは, き裂先端近傍の $K_{I I}=0$ が満たされる方向に進展することが, 線形破壊力学に よって示されている(14) (15). しかし, 熱応力によって 進展するき裂の先端に, 蛇行のような複雑なき裂進展 方向の変化を与える応力場がどのように現れ, 時間的 に変動しているかは不明である. き裂の蛇行に関する 力学的機構を明らかにするためには, 実験を通じてき 裂先端応力場を詳細に測定する必要があるが, そのた めには, き裂進展形態に及ぼす種々の要因を, あらか じめ把握することが不可欠である。

そこで本研究では, ガラス平板中を熱応力によって 進展するき裂の進展形態に及ぼす種々の要因として, はじめに, 温度差 $\Delta T$, 降下速度 $v$ の影響を従来の研 究と同様に調べる. その上で, き裂進展形態に及ぼす 他の要因として, 従来の研究では調べられていなかっ たき裂進展開始位置とき裂進展形態の関係, および, き裂が曲進している場合のき裂進展形態の変化を調 ベる.

\section{2. 実 験 方 法}

図 1 に, 実験装置の概略を示す. 実験装置は, 試験片 


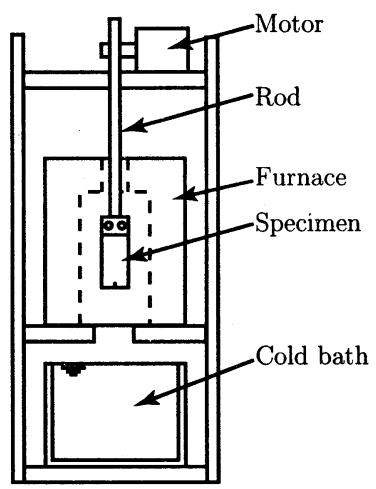

Fig. 1 Experimental apparatus.

Table 1 Properties of soda-lime glass

\begin{tabular}{lll}
\hline Young's Modulus & $E$ & $71.6[\mathrm{GPa}]$ \\
$\begin{array}{l}\text { Poisson's Ratio } \\
\text { Coefficient }\end{array}$ & $\nu$ & 0.20 \\
$\quad$ & & \\
$\quad$ of linear expansion & $\alpha$ & $8.70 \times 10^{-6}[1 / \mathrm{K}]$ \\
Density & $\rho$ & $2500\left[\mathrm{~kg} / \mathrm{m}^{3}\right]$ \\
Thermal conductivity & $\lambda$ & $1.005 \times 10^{-6}[\mathrm{~J} / \mathrm{m} \mathrm{s} \mathrm{K}]$ \\
Specific heat & $c$ & $921[\mathrm{~J} / \mathrm{kg} \mathrm{K}]$ \\
Thermal diffusivity & $\kappa$ & $0.436 \times 10^{-6}\left[\mathrm{~m}^{2} / \mathrm{s}\right]$ \\
Fracture toughness & $K_{I c}$ & $0.76\left[\mathrm{MN} \mathrm{m}^{-3 / 2}\right]$ \\
\hline
\end{tabular}

を加熱するための電気炉，試験片を冷却するための水 槽，試験片を取り付けるロッドとそれを昇降させるた めのモーターからなる、試験片には, 板厚が $1 \mathrm{~mm} の$ ソーダーライムガラスを用いる. ソーダーライムガラ スの物性值を表 1 に示す. 図 2 に本研究で使用した, 3 種類の試験片の形状を示す.これらの試験片には, 熱 応力によるき裂の進展を促進させるため, 初期き裂を 導入してある. 初期き裂は, 試験片の片側表面にガラ ス切りで傷をつけた後, その裏側表面の傷の上から点 荷重を加えて進展させることにより, 板厚方向に貫通 している. 図 2(a), (b) は一定の板幅をもつ試験片で あり, 初期き裂導入位置が異なる. 図 3(c) は, 板幅が 変化する試験片である. この試験片を電気炉で一定時 間加熱した後,一定速度で水槽内に降下させて冷却す る. 実験は試験片温度と水温との温度差 $\Delta T$ と, 降下 速度 $v$ を変えながら行う.このとき, 試験片温度は, 電気炉で一定時間加熱後に電気炉温度と等しくなるこ とを仮定し，電気炉温度とする。

\section{3. 実 験 結 果}

$3 \cdot 1$ き裂進展形態の再現性 はじめに, 図 2(a) の試験片を用いた結果から, 本研究で得られるき裂進 展形態の再現性を示す. 図 3(a), (b), (c) 中の 2 例の

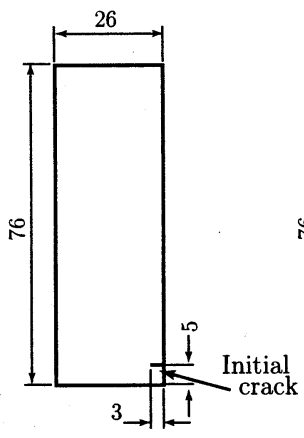

(b)

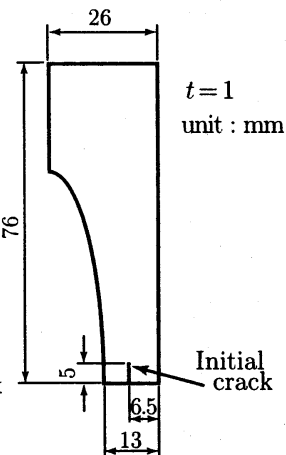

(c) (a)

Fig. 2 Specimen geometries.

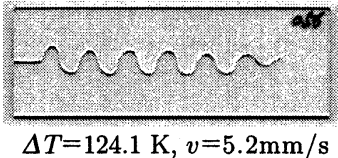

(a)

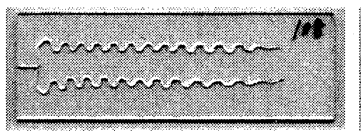

$\Delta T=135.2 \mathrm{~K}, v=3.1 \mathrm{~mm} / \mathrm{s}$

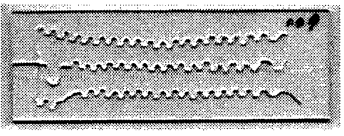

$\Delta T=173.0 \mathrm{~K}, v=2.1 \mathrm{~mm} / \mathrm{s}$

(c) (b)

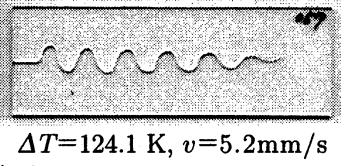

()

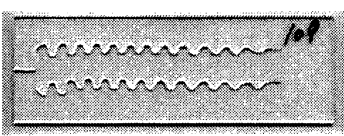

$\Delta T=135.0 \mathrm{~K}, v=3.1 \mathrm{~mm} / \mathrm{s}$

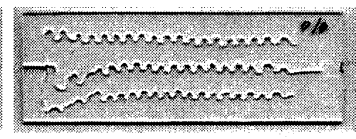

$\Delta T=173.0 \mathrm{~K}, v=2.1 \mathrm{~mm} / \mathrm{s}$

Fig. 3 Examples of experimental results.

実験結果は，それぞれ同じ実験条件下によって得られ たき裂であり，図中には実験条件を明記してある.図 3 に示した試験片は, 左端から水中に降下させた. 試 験片の右端は, 試験片の保持部であり, き裂が保持部 に達する前に, 水槽内への試験片の降下を停止し, き 裂進展を停止させた。

図 3(a) は, き裂進展開始直後にき裂が蛇行した実 験結果を示している．2 例の結果においてき裂経路の 振幅と波長が等しいことがわかる. 図3(b) は, き裂進 展開始直後に 2 つのき裂に分岐した実験結果を示して いる. 分岐後, 2 つのき裂は, 互いの距離を一定に保 ちながら, 蛇行を続けていることがわかる. この場合 においても，2 例のき裂伝播経路の振幅と波長は等し いことがわかる. 図 3(c) は, き裂進展開始直後に 3 つ のき裂に分岐した実験結果を示している. 分岐後, す べてのき裂が蛇行を開始する前は，2 例の結果におい てき裂進展経路がわずかに異なる.しかし, すべての 


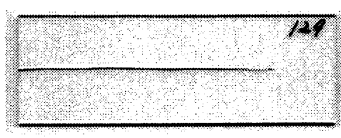

$\Delta T=99.6 \mathrm{~K}, v=8.4 \mathrm{~mm} / \mathrm{s}$

(a)

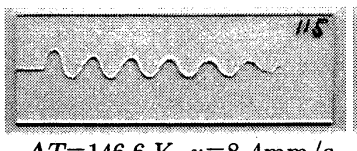

$\Delta T=146.6 \mathrm{~K}, v=8.4 \mathrm{~mm} / \mathrm{s}$

(c)

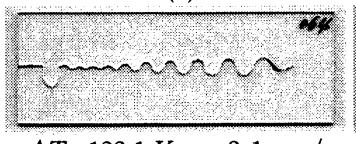

(e)

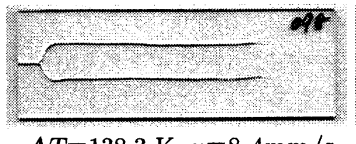

(g)

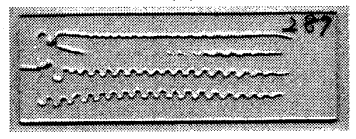

$\Delta T=180.4 \mathrm{~K}, v=3.1 \mathrm{~mm} / \mathrm{s}$

(i)

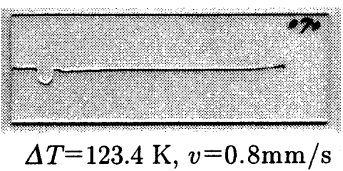

(b)

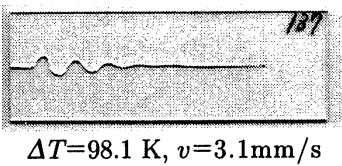

(d)

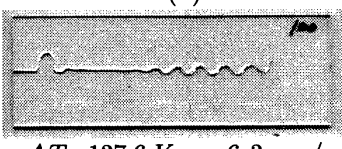

(f)

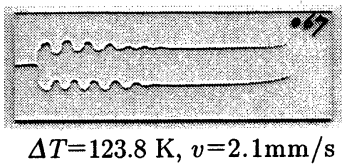

(h)

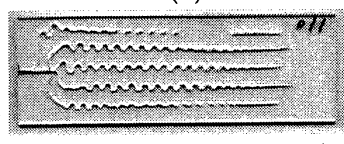

$\Delta T=172.6 \mathrm{~K}, v=0.8 \mathrm{~mm} / \mathrm{s}$ (j)
Fig. 4 Classification of crack propagation patterns. (a) and (b) are straight cracks. (c), (d), (e) and (f) are oscillating cracks, (g), (h), (i) and (j) are branched cracks.

き裂が蛇行を開始すると, き裂伝播経路の振幅と波長 は，2例の結果においてほぼ等しいことがわかる. 図 3 は，実験条件によってき裂伝播の形態は異なるが，同 一の実験条件下においては, き裂が蛇行・分岐した場 合においても同じ進展形態が得られることを示してお り，実験は再現性が極めて高いことを示している.

\section{$3 \cdot 2$ 一定板幅の試験片中におけるき裂進展形態}

3.2.1 冷却側境界からのき裂進展図 3 に示さ れるように, 実験条件によってき裂進展形態は変化す る. 本研究では, Yuse ら ${ }^{(4)}$ と同様に, その進展形態 を大きく 3 つに分類した. 図 4 は, 図 $2(\mathrm{a})$ の試験片 を用いて得られた，3つの進展形態の例を示している.

図 4(a)，(b) は進展形態を直線き裂に分類したき裂 を示している.図 4(a) のき裂は, 初期き裂からのき 裂伝播開始からき裂伝播を停止させるまで，き裂が直 進している.図 4(b) のき裂は, 初期き裂からき裂伝 播開始後, 冷却による熱衝撃によって大きく曲進して いるが，その後試験片中央を直進している. 図 4(a), (b)

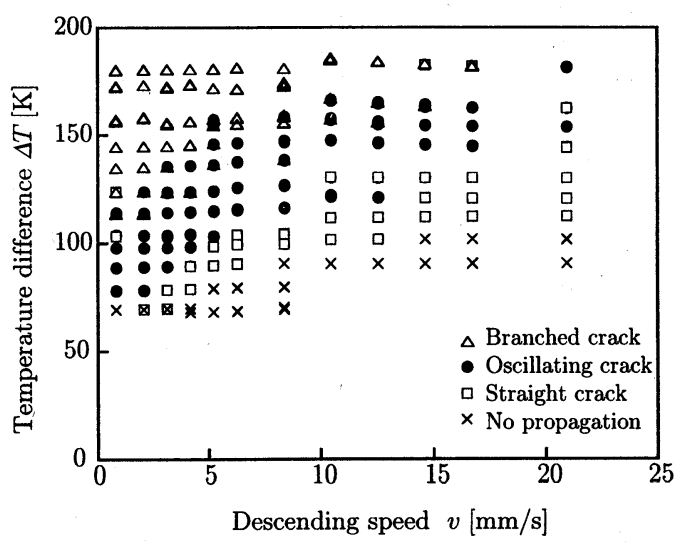

Fig. 5 Clasification of crack propagation patterns.

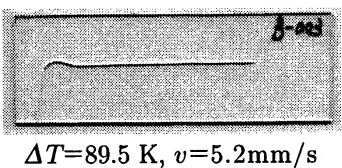

(a)

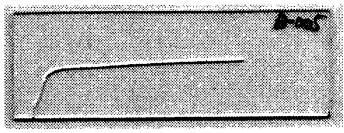

$\Delta T=89.1 \mathrm{~K}, v=8.4 \mathrm{~mm} / \mathrm{s}$

(c)

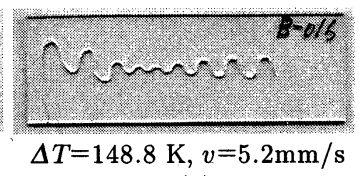

(b)

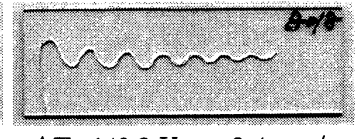

(d)
Fig. 6 Crack propagation from side boundary.

のき裂は，その伝播経路のほとんどの部分が直進であ ることから, 直進き裂として分類した.

図 4(c)〜(f) は, 進展形態を蛇行き裂に分類したき 裂を示している. 図 4(c) は, 進展停止まで進展経路 がほぼ同じ振幅・波長を有する蛇行き裂, 図 4(d) は, 振幅が減衰する蛇行き裂, 図 4(e), (f) は, き裂進展 にしたがって振幅が増大する蛇行き裂を示している. これらのき裂は, き裂進展中に複数回の曲進が観察さ れるため蛇行き裂として分類した。

図 $4(\mathrm{~g}) \sim(\mathrm{j})$ は, 進展形態を分岐き裂に分類したき 裂を示している. 図 $4(\mathrm{~g})$ は, 2 つ直進き裂に分岐 した場合, 図 4(h)，(i)，(j) は，それそれ 2つ，4つ， 5 つの蛇行き裂に分岐した場合を示している.これら のき裂は, すべて初期き裂からの進展開始直後に複数 のき裂に分岐していることから, 分岐き裂として分類 した.

図 5 は, 種々の実験条件におけるき裂伝播形態を図 4 の方法で分類した結果を示している. 横軸は試験片 の降下速度 $v$, 縦軸は温度差 $\Delta T$ である. 図 5 から, 


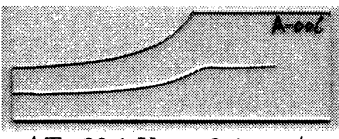

$\Delta T=90.1 \mathrm{~K}, v=2.1 \mathrm{~mm} / \mathrm{s}$

(a)

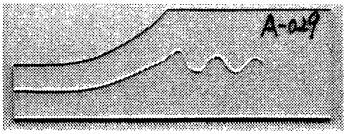

$\Delta T=149.2 \mathrm{~K}, v=8.4 \mathrm{~mm} / \mathrm{s}$

(c)

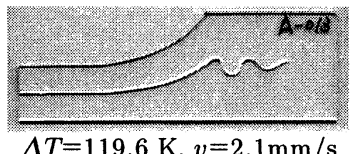

(b)

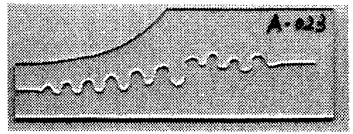

$\Delta T=149.8 \mathrm{~K}, v=2.1 \mathrm{~mm} / \mathrm{s}$

(d)
Fig. 7 Crack propagation in the specimens with varying width.

一定の速度で試験片を降下させる場合, 温度差が大き くなるにつれてき裂の伝播形態は，直進，蛇行，分岐 へと複雑な伝播形態へ変化することがわかる．一方， 一定の温度差においては，試験片の降下速度が大きく なるにつれてき裂の伝播形態は分岐, 蛇行, 直進へと 単純な伝播形態に変化することがわかる. 図 4,5 か ら, 熱応力によるき裂の進展形態は, 温度差 $\Delta T$, 降 下速度 $v$ に依存することがわかる.

$3 \cdot 2 \cdot 2$ 側面境界からのき裂伝播 図6に, 図 2(b) の試験片を用いた結果を示す. 図6において, 試験片は 左端から水中に降下させた．図 6 に示すように，初期 き裂導入位置を変えると, き裂は試験片中央に向かっ て進展した後, 試験片中央で曲進して, 試験片中央に 沿って進展することがわかる. 試験片中央に沿って進 展している際のき裂進展形態は, 図6(a)，(c) はそれ ぞれ直進，(b)，(d) はそれぞれ蛇行である．図 6(a)， (c) の実験条件は, 図 5 に示した直進き裂の実験条件 と一致する．また，図 6(b)，(d) の実験条件は，図 5 に示した蛇行き裂の実験条件と一致する．このことは， 試験片中央をき裂が伝播するときの進展形態は, 初期 き裂導入位置に依存しないことを意味している。

$3 \cdot 3$ 板幅が変化する試験片中におけるき裂進展形態 図 7 に, 図 2(c) の試験片を用いた結果を示す. 図 7 が 示すように，熱応力によって進展を開始したき裂は， き裂進展形態に関わらず，試験片の中央部に沿って曲 進していることがわかる.このことから，き裂進展方 向は試験片境界の影響を強く受けることがわかる．熱 応力を受ける有限幅の帯板では, 帯板中央部において 最も応力が大きいことが示されている(16). したがっ て，き裂が板幅の変化する試験片の中央部を進展する のは, 熱応力を受ける有限幅の帯板において, 板幅中 央が最も応力が大きくなることに関連する.

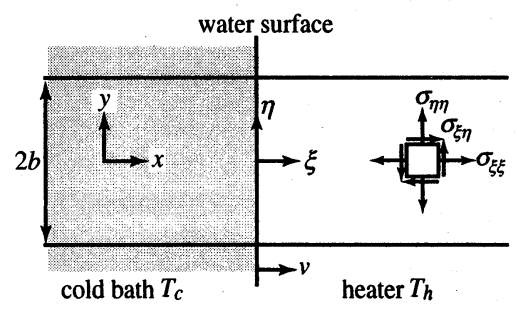

Fig. 8 Coordinate system for a quenching plate.

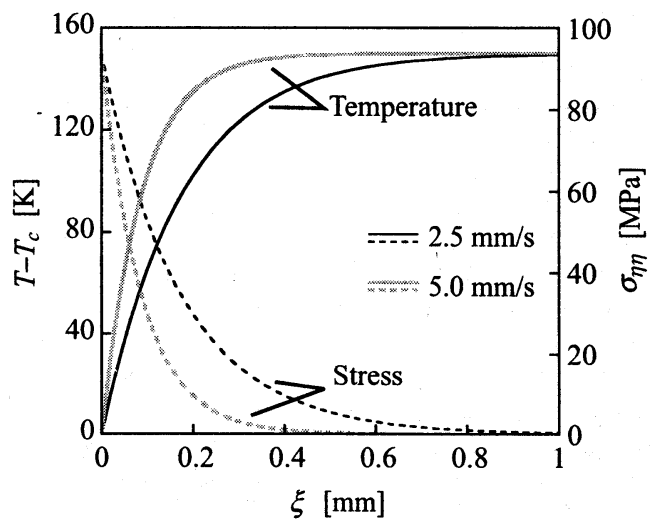

Fig. 9 Temperature and stress distribution as a function of distance from the water surface.

図 7(b)，(d) においては，き裂が試験片の中央部に 沿って曲進した後, き裂が板幅が $26 \mathrm{~mm}$ の位置に達す ると，その直後にき裂は蛇行している．板幅が $26 \mathrm{~mm}$ の位置でき裂が蛇行する 2 例の実験条件は, 図 5 の 蛇行き裂の実験条件と一致する. 一方, 左端の初期き 裂からの進展開始直後におけるき裂形態を見ると, 図 7(a)，(b)，(c) は直進，図 7(d) は蛇行である.しかし， 図 7 の進展形態を示す実験条件は, 図 5 のそれぞれの 進展形態に対応する実験条件とは一致しない。このこ とから，き裂進展形態は試験片の板幅に依存すること がわかり，図 5 と図 7 の比較から板幅が大きくなるに つれき裂進展形態が複雑になることがわかる.

\section{4. 検討}

熱応力によるき裂進展形態の変化を, 定性的に説明 するため，一定速度で冷却される無限平板の応力場を 考える.

図 8 に示す平板に固定された $x y$ 座標系において, 平 板の温度場は熱伝導方程式に従う. いま, 速度 $v$ で水面 とともに移動する $\xi \eta$ 座標系を導入すると, $\xi=x-v t$, 
$\eta=y$ であるから, 熱伝導方程式は,

$$
\frac{\partial^{2} T}{\partial \xi^{2}}+\frac{v}{\kappa} \frac{\partial T}{\partial \xi}=0
$$

となる.ここで， $\eta$ 方向に温度分布がないこと，熱伝 達がないこと, $\xi \eta$ 座標系で定常状態であることを仮 定した.また， $\kappa$ は平板の温度伝導率である. 式 $(1)$ を境界条件

$$
T=T_{h}(\xi \rightarrow \infty), T=T_{c}(\xi \leq 0)
$$

のもとで解くと， $\xi \geq 0$ における平板の温度場は，

$$
T=\Delta T[1-\exp (-v \xi / \kappa)]+T_{c}
$$

となる.ここで, $\Delta T=T_{h}-T_{c}$, である.

一方, 平面熱応力問題における熱弾性変位ポテン シャル $\Phi$ の支配方程式は, 次式で表わされる.

$$
\frac{\partial^{2} \Phi}{\partial \xi^{2}}+\frac{\partial^{2} \Phi}{\partial \eta^{2}}=(1+\nu) \alpha \tau
$$

ここで， $\alpha ， \nu$ はそれぞれ平板の線膨張係数，ポアソ ン比， $\tau=T-T_{h}$ である. 式 (3), (4) から $\Phi$ の特解 を求めると

$$
\Phi=-(1+\nu) \alpha \Delta T(\kappa / v)^{2} \exp (-v \xi / \kappa)
$$

となる．熱弾性変位ポテンシャルと応力の関係 ${ }^{(17)}$ 用いると，平板の応力成分は，

$$
\sigma_{\eta \eta}=E \alpha \Delta T \exp (-v \xi / \kappa), \sigma_{\xi \xi}=\sigma_{\xi \eta}=0
$$

となる.ここで, $E$ は平板のヤング率である. 式 (6) で表わされる応力場は, 無限の板幅をもつ平板の応力 場である. 図 8 のように, 有限幅の帯板の場合や, き 裂を有する場合は, 式 (6) の解に境界值問題の解を重 ね合わせ, 帯板境界およびき裂面での境界条件を満足 させる必要がある.しかし, 熱応力によるき裂進展形 態の変化を, 定性的に説明するためには, 式 (6) の解 で十分であるため，ここでは境界条件を満足する完全 解については言及しない。

式 (3), (6) から求められる, $T-T_{c}, \sigma_{\eta \eta}$ を図 9 に 示す. 横軸は水面からの距離 $\xi$, 縦軸は $T-T_{c}, \sigma_{\eta \eta}$ である. 図 9 では温度差 $\Delta T$ を一定とし, 速度 $v$ を 変化させてある. 図 9 からわかるように, 平板の降下 速度 $v$ が小さくなるにつれて, 水面上方に応力場の形 成される領域が大きくなる. 図 9 では $\Delta T$ を一定とし たが，式 (6) から明らかなように $\Delta T$ が大きくなるに つれ, 応力 $\sigma_{\eta \eta}$ が大きくなる. すなわち, 温度差 $\Delta T$ が大きくなるにつれ, また, 降下速度 $v$ が小さくなる につれ，平板に蓄えられる弾性エネルギ一が大きくな
ることがわかる. また，平板に蓄えられる弾性エネル ギ一の総和が, 平板全体の積分值となることを考える と, 板幅が大きくなるにつれ弾性エネルギーが大きく なることがわかる。

本研究の実験結果は, 温度差 $\Delta T$ が大きくなる場合, 試験片の降下速度 $v$ が小さくなる場合，板幅が大きい 場合に，き裂進展形態は複雑になることを示した.こ うしたき裂進展形態の変化は, 式 $(6)$ の $\sigma_{\eta \eta}$ から得ら れる弾性エネルギ一量の増加に対応していることがわ かる.

\section{5. 結 論}

ガラス平板中を熱応力によって進展するき裂の進展 形態に及ぼす種々の要因として, 温度差, 降下速度の 影響を調べた。その上で, き裂進展形態に及ぼす他の 要因として, き裂進展開始位置と, 曲進き裂の進展形 態を新たに調べ，以下の結論を得た。

（1）熱応力によるき裂進展形態は, 温度差, 降下速度, 板幅に依存して変化する.き裂進展形態の変化は, 平板中に蓄積される弾性エネルギ一が大きくなる につれて複雑になる.

（2）熱応力によるき裂進展形態は，初期き裂位置には 依存しない。

（3）熱応力によるき裂進展において，き裂進展方向は 平板境界の影響を強く受ける．また，平板境界の 影響を受けてき裂が曲進する場合においても，き 裂進展形態は温度差, 降下速度, 板幅によって決 定される.

\section{文献}

(1) Hirata, M., Experimental Studies on Form and Growth of Cracks in Glass Plate, Scientific Papers of the Institute of Physical and Chemical Research, Vol.16, No.332, (1931), pp.172-195.

(2) Sato, Y. and Watazumi, T., A New Method of Cutting Glass Plate, Using Thermal Stress, Journal of Mechanical Working Technology, Vol.1, (1977), pp.169-182.

(3) Imai, Y. et. al., Thermal Stress Cleaving near a Free Edge Using a Moving Heat Source (in Japanese), Transactions of the Japan Society of Mechanical Engineers, Series A, Vol.68, No.670, (2002), pp.993998.

(4) Yuse, A. and Sano, M., Transition between crack patterns in quenched glass plates, Nature, Vol.362, No.6418, (1993), pp.329-331.

(5) Yuse, A. and Sano, M., Instabilities of quasistatic crack patterns in quenched glass plates, Physica $D$, Vol.108, (1997), pp.365-378.

(6) Yang, B. and Ravi-Chandar, K., Crack path instabilities in a quenched glass plate, Journal of 
the Mechanics and Physics of Solids, Vol.49, No.1, (2001), pp.91-130.

(7) Sumi, Y. and Mu, Y., Morphological Aspects of Thermally Induced Wavy Cracks in a Brittle Solid (in Japanese), Transactions of the Japan Society of Mechanical Engineers, Series A, Vol.66, No.642, (2000), pp.361-368.

(8) Marder, M., Instability of a crack in a heated strip Physical Review E, Vol.49, No.1, (1994), pp.R51R54.

(9) Hayakawa, Y., Numerical study of oscillatory crack propagation through a two-dimensional crystal, Physical Review E, Vol.49, No.3, (1994), pp.R1840R1807.

(10) Sasa, S. et. al., Oscillatory instability of crack propagations in quasibrittle fracture, Physical Review E, Vol.50, No.3, (1994), pp.R1733-R1736.

(11) Bahr, H. A. et. al., Oscillatory instability in thermal cracking, Physical Review E, Vol.52, No.1, (1995), pp. $240-243$.
(12) Adda-Bedia, M and Pomeau, Y., Crack instability of a heated glass strip, Physical Review E, Vol.52, No.4, (1995), pp.4105-4113.

(13) Adda-Bedia, M and Amar, M. B., Stability of quasiequilibrium cracks under uniaxial loading, Physical Review Letters, Vol.76, No.9, (1996), pp.1497-1500.

(14) Oleaga,G.E., Remarks on a basic law for dynamic crack propagation, Journal of the Mechanics and Physics of Solids, Vol.49, No.10, (2001), 2273-2306.

(15) Oleaga,G.E., On the dynamics of cracks in three dimensions, Journal of the Mechanics and Physics of Solids, Vol.51, No.1, (2003), 169-185.

(16) Timoshenko,S. and Goodier,J.N. Theory of Elasticity 2nd ed., (1951), McGraw-Hill, New York.

(17) Noda,N, Hetnarski,R.B. and Tanigawa, Y. Thermal Stresses 2nd ed., (2003), Taylor and Francis. 